Semarang

State University

Undergraduate

LAWE

SOCIETY

REVIEW

VOLUME 1 ISSUE 2, JULY 2021
ISSN (Print): 2807-8225 ISSN (Online): 2807-8683

History of Article

Submitted: December 2020

Revised: March 2021

Accepted: May 2021

How to cite:

Wahyuni, R. T. (2021). Capital Punishment and (in)Justice. Semarang State University Undergraduate Law and

Society

Review, 1(2),

141-160.

https://doi.org/10.15294/lsr.v1i2.50548

(C) 2021 Authors. This work is licensed under a AttributionNonCommercial-ShareAlike 4.0 International (CC BY-NC-SA 4.0). All writings published in this journal are personal views of the authors and do not represent the views of this journal and the author's affiliated institutions.

\title{
Capital Punishment and (in)Justice
}

\section{Ribut Tirto WAHYUNI@}

Faculty of Law, Universitas Negeri Semarang

Sekaran, Gunungpati, Semarang 50229, INDONESIA

凶ributtirto31@gmail.com

\begin{abstract}
Indonesia is a legal state that upholds justice based on Article 1 paragraph 3 of the 1945 amendment. However, the legal condition in Indonesia is currently heavily criticized by the people, especially the small people. Laws in Indonesia are often called blunt-sharp laws that are triggered by the weakness of law enforcement in Indonesia. The condition of justice law in the increasingly bad state of Indonesia greatly affects the health and democratic forces in Indonesia. Failure to realize justice through law in Indonesia must be immediately addressed for the creation of a just state of justice as stipulated in the content of Pancasila. Law enforcement in Indonesia is not in accordance with Article 1 Paragraph 3 of the 1945 Amendment of Amendment which states that Indonesia is a State of law.
\end{abstract}


This study aims to analyze the capital punishment in the context of justice and fairness, as well as human rights perspective.

KEYWORDS. Capital Punishment; Justice; Fairness; Human Rights

\section{INTRODUCTION}

The punishment of a criminal, its suffering, and part of the elements of the criminal law (Arief, 2010). The suffering is even until after a criminal/ punishment (Sudarto, 1981). Hierarchically Article 10 letter a of the Criminal Code places the death penalty as the most severe punishment (Rodiyah, 2011). Death penalty from ancient times through customary law, however the issue of the death penalty has always been a debate between agree and disagree (Arief, 2013). The counter-group with the reasons: the absolute nature, the human rights, and the goal of crime (Bakhri, 2009), the groups which agree in Indonesia by the reasons of the diversity, the area and the number of apparatus (Bakhri, 2009; Fajrin, Purnamasari, Rosyida, \& Maulidiyah, 2020).The debate about the death and execution is also associated with effectiveness (Barnabas, 2014) and globally through the institution of International Amnesty called on the UN member states to remove death penalty in its criminal legal system.

Normatively the government has the basic authority to execute death. Among others are in Law Number 1 of 1946 About the Criminal Code, Law Number 2 PNPS in 1964 Concerning the Procedures for the Criminal Implementation Done by Courts within the General and Military Courts, enacted by Law Number 5 Year 1969, and Law Number 8 of 1981 about KUHAP (Indonesian Procedural Penal Code) (Kania, 2014; Solihah \& Masyhar, 2021).

Though of the philosophical understanding is often associated with local wisdom, which is traditional connotation, in other words look past or backward. The understanding of society is changing from different times 
and places even though the national law enforcement is the same. The problem of community understanding in Riau Indonesia, known as Malay society and thick with the values of customs, can be a problem in relation with the philosophical basis of legislation on the execution of capital punishment. The fact, in Riau, some agree, and some disagree (Afrizal, 2019; Wahyudi, 2012). The Different understanding of society will continue so that the only way for the gradation of the difference can be found to be review, as well as put all of this matter into the realm of legal philosophy, especially in the light of paradigmatic studies (Indarti, 2015; Anjari, 2018).

The paradigm base on this philosophical study will make it easier to find new scientific truths when an anomalous condition occurs. Because the paradigm is not only a collection of theories, but also the benchmarks, which defines the required standards of the accuracy, determines the right method of research or the way in which the results of the research will be interpreted. In short, the paradigm offers the following problem model solutions (Indarti, 2010; McRae, 2017; Ahmad, 2021).

Through the paradigmatic studies, the understanding of society and the philosophical foundations of legislation toward the execution of capital punishment is the basic belief or worldview. it can be traced and sorted into the ontology, epistemology, and methodology. It can be seen how the dynamics of the relationship between the different understanding of society and the philosophical foundations for the legislation on the execution of capital punishment. It also can be traced based on the different background experiences.

The research process can be seen as a series of interrelated phases and cannot be separated from one another. Denzin and Lincoln in "Introduction: Entering the field of Qualitative Research" in Handbook of Qualitative Research" (1994): as quoted by Agus Salim (2006) presents five phases which are a series of research processes. The Standpoint of this research relates to a tradition that will guide researchers as long as the research process (Indarti, 2015). Tradition in research is grouped into quantitative research and qualitative research. This research will use the 
qualitative research tradition. Bogdan and Taylor define a qualitative methodology as a research procedure that produces descriptive data in the form of written or oral words of observable persons and behaviors (Moleong, 2006).

Furthermore, this study uses a paradigm which etymologically, the word paradigm is actually derived from the mixed word, combination from the Greek paradeigma, the meanings is next to, on the side, side by side or on edge. While deiknunai or deigma means view or show (Indarti, 2010). Guba and Lincoln, in the Handbook of Qualitative Research, Paradigm is a major philosophical system, parent or umbrella, which includes certain ontologies, epistemologies and methodologies that cannot be simply exchanged, represents a certain beliefs system, which provides the way in which the world is seen, understood, and learned, in other words associating its adherents with a particular worldview (Denzin \& Lincoln, 2000).

The approach and method of this study related to a normative legal research and empirical/sociological law research term, FX.Adji Samekto mentions: to determine the research is normative or empirical seen from the goal to be achieved (Samekto, 2015). Soetandyo Wignyosoebroto is called the doctrinal method. is a method of legal research based on rules that require that its adherence can be enforced by the use of state power (normative), acting in the world of necessities (das sollen), and the product is also religious (Sidharta, 2013). The types of data required in this study are primary data and secondary data. Secondary data will use literature study and Primary Data is data obtained from main source directly by purposive way. Primary data sources include: the legislative members (DPRD), member of the Political Parties; executive (Local Government); Religion leaders, ethics leaders and community leaders; NonGovernmental Organization (NGO); Judicial apparatus (Police, Prosecutors, and Judges); Private party; Press area; Academics; College student; Human rights activist; Female activist; and Ordinary people. Primary data collection, conducted through the dissemination of 
Questioners and interviews, in the Pekanbaru city as representing the metropolis of Riau community (Riau Data Center, 2014) and Siak Sri Indrapura representing the traditional mindset people of Riau (Wikipedia, Kesultanan Siak, 2017). After the data was collected then conducted the focus group discussion (FGD). Lastly, the data were interpreted based on the methodology of hermeneutics in constructivism.

\section{THE COMMUNITY UNDERSTANDING ON THE IMPLEMENTATION OF DEAD PENALTY IN RIAU PROVINCE}

Historically, before Indonesia independence, some applicable laws were set the threat of criminal punishment in the form of capital punishment (Rodiyah, 2011; Zimring \& Johnson, 2008). The implementation of death penalty regulated in Law No. 2 PNP's 1964. The Implementation Procedures of ten pliers Criminal Dropped by The General Court Papers Courts and Military, promulgated by Law No. 5 of 1969, and the State Police Chief Regulation of the Republic of Indonesia 12 of 2010 on the Implementation of the Criminal Procedure. The implementation of the capital punishment is by firing to death. Historically, in indigenous communities was known that the execution of capital punishment like as: cut the neck, Hanging, burying alive, drowning, and beaten to death (Rodiyah, 2011; Rusito \& Suwardi, 2019; Saputra \& Santoso, 2019).

To know the of society understanding on the execution of capital punishment in Pekanbaru and Siak Regency Community, the researcher found the result in table 1 below: 
Table 1. The Community Understanding on the Implementation of Death Penalty in Pekanbaru City and Siak Regency

\begin{tabular}{lll}
\hline No & Pekanbaru City & Siak Regency \\
\hline 1 & Shot dead & $\begin{array}{l}\text { Agree the death penalty } \\
\text { Shot to die - more soft injected } \\
\text { dead / beheaded / adjusted for } \\
\text { convicted request } \\
\text { There is a deterrent effect } \\
\text { Harmonized / adapted to }\end{array}$ \\
3 & Customary Law Execution & $\begin{array}{l}\text { Disagree capital punishment - } \\
\text { not known in customs. } \\
\text { No execution yet }\end{array}$ \\
\hline
\end{tabular}

Understanding of the execution of capital punishment revealed from the table above, there is a weakness to the legal unification of executing capital punishment. The understanding of the people in Pekanbaru city and Siak regency above, was supported by the results of the questioner as illustrated, it was clearly seen that the people of Pekanbaru city had a fairly high understanding on the implementation of capital punishment in terms of legislation (more than $60 \%$ ). The Siak society, which is a traditional area, the understanding of the community on the execution of capital punishment is very low (of more than $70 \%$ people had lack of understanding). While the state law is the last option if the customary law not able to solve their problems.

From the understanding which presented by Pekanbaru city and Siak regency society, there are similarities and differences between them. The equal understanding on the execution of capital punishment is by shot dead. But if there is problem on the mechanism, Riau society also agree with injection dead, because it is more soft and slightly contain elements of torture. In addition, the majority of people agree with the death penalty as a criminal for certain cases, it is based on the impact of the crime toward the community. 
The people of Pekanbaru understand that execution implementation in Riau has been implemented, but Siak Society said that there is no death execution in Riau, they know the death prisoner was sent to Nusakambangan for execution process. In addition, there is a difference in understanding the aspects of the form of death execution. Pekanbaru society understand that there were some alternatives in the execution of capital punishment by injecting dead / electric chair, or by punishment beheading, or can also be adapted to the request of the convicted person. While the Siak Society understand that the procedure of execution will follow the procedures state law. In the Sakai (one the local ethnic in Riau), the customary Law not knowing capital as the punishment, death is God's business. lastly, the community's understanding on the implementation of capital punishment, it was found that there were $39.48 \%$ of the people in Pekanbaru society do not understand, whereas in Siak Regency community there are $73.44 \%$ of people do not understand.

\section{THE PHILOSOPHICAL PLATFORM OF LAWS REGARDING THE IMPLEMENTATION OF CRIMINAL OFFENSES}

The philosophical foundation is one of the basic enforcements of a legislation (Asshiddiqie, 2014), or generally argue at least should contain three basic foundations: philosophical, juridical, and Political (Astawa \& Na'a, 2008). These three platforms shall jointly be formulated into a legislation (Sinaga, 2005). Philosophical legitimacy is based on ethical (moral) values resulting from philosophical reflection and must conform to the ideals and worldview of society (Nurtjahjo, 2006). At present use values must be explicitly philosophical form of values of Pancasila (Indonesian's state foundation) and the 1945 Constitution.

Consideration of Law Number 2 Pnps Year 1964: "Based on consideration of adjustments to the progress of the state and the spirit of 
the Indonesian revolution ". The philosophical foundation should be listed and contain basic values as the nation's way of life. Prior to the coming into the effect of Law Number 2 of the Pnps of 1964, Article 11 of the Criminal Code was enacted. Mechanism under Article 11 of the Criminal Code by hanging: "The death penalty is executed by the executioner at the hanging point by tying the rope around the neck of the convict, and tying the rope to the gallows, then dropping the board where the convict is standing. There is low Understanding of the Society in Pekanbaru city and Siak Regency toward the philosophical basis of the legislation on the implementation of capital punishment. According to the community, the law does not based on philosophical (48.94\%). Public understanding of Siak was lower $(66.1 \%)$.

The high number of percentages not underlying in the understanding of society based on law No.2 Pnps 1964, There are two phrases that can be withdrawn: - Adjustment with the progress of state progress; and - The soul of the Indonesian revolution. Strictly speaking does not refer to Pancasila and the to the 1945 Constitution, because the development of the state is not oriented to the philosophical foundation but rather to the Sociological Foundation. And the soul of the revolution does not fit its contexts in the situation of developing Indonesia, the soul of the revolution is more suited to the legal political situation in the old order (guided democracy). 


\section{THE DYNAMICS OF RELATIONSHIP (BETWEEN) THE UNDERSTANDING OF SOCIETY AND THE PHILOSOPHICAL PLATFORM OF LEGISLATION ON THE IMPLEMENTATION OF DEADLY CRIMES IN RIAU: A STUDY OF THE CONSTRUCTIVISM PARADIGM}

The dynamics of the relationship between the understanding of society and the philosophical foundation of the law on the implementation of capital punishment in Riau requires the improvement of the execution of capital punishment from several aspects, as follows:

\section{1) Aspects of Legislation}

There was relationship between the understanding of Riau society and the philosophical basis of the legislation on the implementation death penalty, it was constructed through public understanding in Pekanbaru City and Siak regency. The Improvement of the death penalty's implementation in the future can be seen in table 2 below.

Table 2. The Dynamics Relation Between Pekanbaru Society and Siak Society Understanding with Philosophical Basis of Legislation on the Implementation of The Criminal Offense of Legislation Aspects

\begin{tabular}{|c|c|c|}
\hline No & Pekanbaru City & Siak Regency \\
\hline 1 & Respect local wisdom & $\begin{array}{l}\text { The psychological impact of the } \\
\text { public }\end{array}$ \\
\hline 2 & Clear waiting time & Execution time is clear \\
\hline 3 & $\begin{array}{l}\text { Value of Religion, Custom } \\
\text { and International }\end{array}$ & $\begin{array}{l}\text { Capital punishment is necessary } \\
\text { A bit of a painful / torturous } \\
\text { element }\end{array}$ \\
\hline 4 & Execute openly & Transparency in execution \\
\hline
\end{tabular}


Based on the table above, there are similarities and differences as follows: Equation on the form of rapid execution of capital punishment raising death and a bit of torture. In addition, both want to assert the timing of execution. While the difference in the society of Pekanbaru city, there should be a space of forgiveness, and who have been waiting for execution must be changed to criminal for life. As well as improvements to the law there are 3 values to be considered (religious, customary, and international). And the place of execution can be closed even in public places. While understanding Siak society, execution can be done openly to give psychological effect to society and avoid public suspicion to realization of execution die. And the chances to be executed die according to the conviction of the convict's law or according to the sense of community justice.

\section{2) Performance Aspects of the Apparatus}

The dynamics of the relationship between the understanding of society and the philosophical basis of legislation on the execution of capital punishment, there is improvement of the performance aspect of the apparatus. It can be seen in the table 3 below:

Table 3. The Dynamics Relation Between Understanding Society of

Pekanbaru City and Siak Regency with Platform Philosophical Laws Regulations about Implementation of Deadly Criminal Aspects of Performance Apparatus

\begin{tabular}{lll}
\hline No & Pekanbaru City & Siak Regency \\
\hline 1 & Non-legal factors & Selective cutting \\
2 & SOP & Some are already procedural \\
3 & Improvements Openness / & Understanding as a state servant \\
& Transparency & \\
4 & Discriminatory & It needs to be watched \\
\hline
\end{tabular}


The table above shown similarities and differences. The equation is the revamping of the performance of the apparatus, who understand the consequences of the duty of the state servant, the apparatus professionalism, need to avoid bribes. In addition, the equation on the aspects of public performance monitoring, this is to avoid the intervention of certain parties and public suspicion of executions are played. The difference according to the understanding of Pekanbaru society there is some improvement, as there is human, there is an executor educated and experience. In addition, it needs improvement where the officers are still picking cases, always working based on public pressure. Meanwhile, according to the understanding of Siak society, the apparatus understanding on the obligation to carry out the duty of the state, so that the execution of death does not become a psychological burden and for which functioning as informant is not necessarily executed by death.

\section{3) Aspects of Cultural Values (Malay Value)}

Community understanding in Pekanbaru and Siak about the dynamics of the relationship between the understanding of society and the philosophical foundations of legislation on the execution of capital punishment, from the aspect of cultural values (Malay), can be seen in table 4 below:

Table 4. Theme (Main) Dynamics of Relation Between

Understanding of Pekanbaru Town Society and Siak Society with Philosophical Platform Legislation Regulation about Dead Criminal Implementation from Aspect of Cultural Value (Malay)

\begin{tabular}{lll}
\hline No & Pekanbaru City & Siak Regency \\
\hline 1 & Malay is identical with Islam & Malay is identical with Islam \\
2 & Pay attention to local wisdom & $\begin{array}{l}\text { Understanding of Malay cultural } \\
\text { teaching }\end{array}$
\end{tabular}


3 The value of a universal culture

4 Capital punishment does not Involves customary functionaries fit the culture

Based on the table above, there are similarities and differences as follows: The similarity is Malay Culture identical with Islam and in Islam claim to be capital punishment. Legal reform should consider local wisdom/Malay cultural values, also known as Malay cultural teaching. Meanwhile, difference is majority Pekanbaru society demanded the capital punishment because it has become a universal value, although it can be adapted to the context of indigenous culture. While in Siak society need to strengthen the value of consensus and the government must allocate budget to involve functionaries of customary institutions to play a role in coaching.

\section{4) Aspects of Supervision and Development}

The understanding of Pekanbaru and Siak society about the dynamics of relations between society and the philosophical foundations of understanding of laws and regulations on the implementation of capital punishment, from the aspect of control and coaching can be seen in Table 5 as follows:

Table 5. Theme (Main) Dynamics of Relation Between Understanding Society of Pekanbaru City and Siak Society with Philosophical Platform Legislation Regulation about Implementation of Deadly Crime from Monitoring and Coaching Aspect

\begin{tabular}{lll}
\hline No & Pekanbaru City & Siak Regency \\
\hline 1 & Judges and the public are & $\begin{array}{l}\text { Supervision and Transparency } \\
\text { are required }\end{array}$ \\
& watching & By the rules \\
3 & Immediate execution & Weak supervision
\end{tabular}


Based on the table above, there are similarities and differences as follows: Equation such as the need to control both internally and externally, either by forming a team, to oversee the implementation time, intervention and influence other countries are legal counsel. In addition, the equation is consistent in enforcing the rule of execution of capital punishment, because it will harm the right of the state and the right of prisoners, in Pekanbaru the process of coaching does not need isolation/rights of prisoners. Besides need value awareness, "God forgiving", and build consciousness from the beginning accompanied until repentance faces death. It needs a regulation to replace law to confirm the deadline for the execution process. The understanding of Siak regency society should be independent, and oversight monitoring is limited, one of the standard supervisions of operational procedures.

\section{5) Aspects of Religious Values}

From the aspect of religious values of the understanding construction the people of Pekanbaru city and Siak regency about the dynamics of the relationship between the understanding of society and the philosophical foundation of the law on the implementation of capital punishment can be seen in table 6 as follows:

Table 6. Theme (Main) Dynamics of Relation Between Understanding

Society of Pekanbaru City and Philosophical Foundation of Legislation Regulation of Dead Criminal Implementation of Religion Value Aspect

\begin{tabular}{lll}
\hline No & Pekanbaru City & Siak Regency \\
\hline 1 & Culture is forgiving & $\begin{array}{l}\text { The death penalty according to } \\
\text { religious belief (Islam) }\end{array}$ \\
2 & Moral / Morals universal & $\begin{array}{l}\text { The death penalty seemed to } \\
\text { precede God }\end{array}$
\end{tabular}


3 According to Eastern custom Need forgiveness (Islamic values are accommodated)

$4 \quad$ Full mentoring $\quad$ Full mentoring/guidance

Based on the table above, there are similarities and differences as follows: The equation is need of guidance from the beginning so that the death row inmates are mentally prepared, that the death sentence is part of destiny. In Islam it is known qisas and the value is universally acknowledged, although there is an element of forgiveness by replacing it with a fine. Whereas the difference between the people of Pekanbaru and the Malay culture is identical to Islam, it is necessary to include the religious values, such as the cultivation of the convicted religiosity about the nature of death/resignation according to destiny, and the beheading there is value/quick to die, for it is necessary involved MUI (the council of Indonesian Moslem's Leader)/religious/religious organizations. In addition to speed up the execution process needs a breakthrough of the president to cut the chain of bureaucracy/reject the request. While the understanding of the Siak community as law comes from God, one side of execution dies before the law of God over one's life. In Islam qisas (capital punishment) is not contrary to the religious beliefs of Islam.

\section{6) Aspects of Changes in Global Value}

Aspect of change of Global value, the result of the construction of the elements of the mind of the society of Pekanbaru and Siak Regency about the dynamics of the relation between the understanding of society and the philosophical foundation of the legislation about the execution, can be seen in table 7 as follows: 
Table 7. Theme (Main) Dynamics Relation Between Understanding

Society of Pekanbaru Town and Siak Regency with Platform

Philosophical Laws Regulation about the Imprisonment of the Dead

Criminal of Aspects of Changes of Global Value

\begin{tabular}{|c|c|c|}
\hline No & Pekanbaru City & Siak Regency \\
\hline 1 & $\begin{array}{l}\text { Countries should not } \\
\text { intervene }\end{array}$ & $\begin{array}{l}\text { The death penalty is still } \\
\text { necessary }\end{array}$ \\
\hline 2 & $\begin{array}{l}\text { Indonesia is still low } \\
\text { civilization }\end{array}$ & $\begin{array}{l}\text { The abolition of capital } \\
\text { punishment must be at the same } \\
\text { level }\end{array}$ \\
\hline 3 & Need balance & Change the total mind set \\
\hline 4 & $\begin{array}{l}\text { There should be a waiting } \\
\text { time }\end{array}$ & $\begin{array}{l}\text { State Consideration of } \\
\text { International Institutions - for the } \\
\text { good of the nation }\end{array}$ \\
\hline
\end{tabular}

Based on the table above, there are similarities and differences as follows: The equation is not the time yet to eliminate capital punishment, because civilization is still low, or mind set has not changed completely. Besides, not all that brought west is suitable, to protect the national interest. While the difference is, the understanding of Pekanbaru society that, the state should not be intervened, or the rule of law is enforced. Mainstream abolition of the death penalty has not touched the substance appears even injustice. The legal purpose it is necessary to balance, for instance global Islamic values. Whereas the Siak Society's understanding, that the death penalty is the authority of the state, the abolition of capital punishment can be carried out if there is a punishment equal to capital punishment, besides the authority to eliminate life is the mutual possession of God, the State and human being are not authorized. And the State needs to weigh to accommodate the values offered by the International Ham commission and international amnesty institutions with due regard to the good of the Indonesian nation. 
The importance of improvement based on the dynamics of the relationship between the understanding of society and the philosophical basis of legislation on the execution of capital punishment above, supported by data of questioners results from elements of society in Pekanbaru and Siak regency. Understanding of Pekanbaru municipal society on the dynamics of the relationship between the understanding of the society and the philosophical basis of the legislation regarding the implementation of capital punishment above (the suitability of the philosophical basis of legislation on the execution of capital punishment with the existing values in the community in Riau), which is based on some indicator of understanding, the overall understanding of the city of Pekanbaru to the appropriateness of the philosophical basis of legislation on the execution of capital punishment with the values that exist in the community in Riau is still not appropriate, because the numbers were not high $(45.22 \%)$. as well as the understanding of the Siak district community on the suitability of the philosophical foundation of the law on the implementation of capital punishment with the values that exist in the community in Riau is not appropriate because the unsuitable (63.96\%).

\section{CONCLUSION}

The public understanding about the execution of capital punishment in Riau is People still want the existence of capital punishment as one of the criminal forms in positive law. Despite another understanding of the way in which it is practiced by injecting dead or by an electric chair or by beheading or adjusting to the wishes of the convicted person. Although the understanding percentage of still relatively low (Pekanbaru $39.48 \%$ and Siak regency 73.44\%). Philosophical foundations of the law Implementation to the death penalty, there are two phrases: Adjustment to the progress of the situation; and the soul of the Indonesian revolution. The development of circumstances is not oriented to philosophical foundations but rather to sociological grounds. And the soul of the revolution does not 
fit the context in the situation of Indonesia build. According to the understanding of the people in Riau Province (Pekanbaru and Siak) the law does not underlie the basic values of Pancasila and the Preamble of the 1945 Constitution of $48.94 \%$ and $66.1 \%$. Paradigm, constructive paradigm can trace the ontology, epistemology, methodology and even the method of execution of capital punishment, and the relationship of the relationship between the understanding of society and the philosophical values that live in the community. The relationship of the relation is conical to the people's desire to improve the implementation of capital punishment from the aspect of legislation, the performance of law enforcement officers, supervision and guidance, the aspects of cultural values, religious values aspect, and the aspect of change of global value. In accordance with the understanding of Pekanbaru City society on the suitability of the philosophical foundation of legislation about the execution of capital punishment with the existing values in the midst of the people of Riau is still not appropriate, because the number is not suitable (Pekanbaru $45.22 \%$, Siak $63.96 \%$ ).

\section{REFERENCES}

Afrizal, A. (2019). Mahasiswa Debatkan Hukuman Mati di Balai Bahasa Provinsi Riau, Online, http://mahasiswa-debatkan-hukuman-matidi-balai-bahasa-provinsi-riau.

Ahmad, I. F. (2021). Why Indonesia Mantain Capital Punishment. Fiat Justicia Jurnal Ilmu Hukum Fakultas Hukum Universitas Lampung, 15(1), 25-38.

Anjari, W. (2018). Penjatuhan Pidana Mati di Indonesia dalam Perspektif Hak Asasi Manusia. E-Journal Widya Yustisia, 1(2), 107-115. https://ejournal.jurwidyakop3.com/index.php/yustisia/article/view/208 
Arief, B. N. (2010). Toeri-Teori dan Kebijakan Pidana. Bandung: PT.Alumni. Arief, B. N. (2013). Kapita Selekta Hukum Pidana,. Bandung: PT.Citra Aditya Bakti.

Asshiddiqie, J. (2014). Perihal Undang-Undang. Jakarta: Rajawali Press.

Astawa, I. G. P., \& Na'a, S. (2008). Dinamika Hukum dan Ilmu Perundangundangan di Indonesia. Bandung: PT. Alumni.

Bakhri, S. (2009). Perkembangan Stelsel Pidana Indonesia. Yogyakarta: Total Media.

Barnabas, D. A. (2014). Perspektif Aliran Filsafat Hukum Terhadap Hukuman Mati, Online. http://cancergoxil.blogspot.co.id/2014/05/perspektif-aliran-filsafathukum.html.

Denzin, N. K., \& Lincoln, Y. (2000). Qualitative Research. USA: Thousand Oaks.

Fajrin, Y. A., Purnamasari, A. P., Rosyida, R. I., \& Maulidiyah, D. F. (2020). Death Penalty for Corruptors in Indonesian Human Rights Perspective. Unnes Law Journal, 6(2), 287-404. https://doi.org/10.15294/ulj.v6i2.40613

Indarti, E. (2010). Diskresi dan Paradigma Sebuah Telaah Filsafat Hukum. Research Report. Semarang: Universitas Diponegoro.

Indarti, E. (2015). Kekuasaan, Otoritas, dan Akuntabilitas Kepolisian dalam Penegakan Hukum: Suatu Telaah Filsafat Hukum. Research Report. Semarang: Universitas Diponegoro.

Kania, D. (2014). Cita Politik Hukum Pidana Mati di Indonesia. Jurnal Ilmu Hukum, 4(2), 161-179.

Kurniawan, S. D. (2020). The Capital Punishment for Narcotic Crime: Pros and Cons in Indonesian Legal System. The Indonesian Journal of International Clinical Legal Education,2(4), 393-406. https://doi.org/10.15294/ijicle.v2i4.43171 
McRae, D. (2017). Indonesian capital punishment in comparative perspective. Bijdragen tot de taal-, land-en volkenkunde/Journal of the Humanities and Social Sciences of Southeast Asia, 173(1), 1-22. https://doi.org/10.1163/22134379-17301002

Nurtjahjo, H. (2006). Filsafat Demokrasi. Jakarta: Bumi Aksara.

Riau Data Center. (2014). "Pekanbaru jadi kota metropolitan mulai tahun depan," 2014. [Online]. Available: www.datacentre.riau.go.id.

Rodiyah, R. (2011). Pembaharuan Hukum Pidana Tentang Eksekusi Pidana Mati Perempuan Hamil. Yogyakarta: Arti Bumi Intaran.

Rusito, R., \& Suwardi, K. (2019). Development of Death Penalty in Indonesia in Human Rights Perspective. Ganesha Law Review, 1(2), 3854. https://ejournal2.undiksha.ac.id/index.php/GLR/article/view/53

Saleh, R. (1959). Masalah Pidana Mati. Yogyakarta: Alsara Baru.

Salim, A. (2006). Teori \& Paradigma Penelitian Sosial. Yogyakarta: Tiara Wacana.

Samekto, F. A. (2015). Pemahaman Dasar Metode Penelitian Hukum. Semarang: Undip Press.

Saputra, A., \& Santoso, F. J. (2019). Death Penalty, Right to Life, and Various Controversies in Human Rights. Unnes Law Journal: Jurnal Hukum Universitas Negeri Semarang, 5(1). https://doi.org/10.15294/ulj.v5i1.35842

Sidharta, S. (2013). Metode Penelitian Hukum, Konstelasi dan Refleksi. Jakarta: Yayasan Obor Indonesia.

Sinaga, B. N. P. D. (2005). Ilmu Pengetahuan Perundang-undangan. Yogyakarta: UII Press.

Solihah, E. N., \& Masyhar, A. (2021). The Implementation of Capital Punishment in Indonesia: The Human Rights Discourse. Journal of Law and Legal Reform, 2(2), 321-328. https://doi.org/10.15294/jllr.v2i2.46625

Sudarto, S. (1981). Hukum dan Hukum Pidana. Bandung: PT.Alumni. 
Wahyudi, S. T. (2012). Problematika Penerapan Pidana Mati dalam Konteks Penegakan Hukum di Indonesia. Jurnal Hukum dan Peradilan, 1(2), 207-234. http://dx.doi.org/10.25216/jhp.1.2.2012.207234

Wikipedia, "Kesultanan Siak Sri Inderapura," 7 September, 2017.

Zimring, F. E., \& Johnson, D. T. (2008). Law, society, and capital punishment in Asia. Punishment \& Society, 10(2), 103-115. https://doi.org/10.1177/1462474507087194

\section{Conflicting Interest Statement}

All authors declared that there is no potential conflict of interest on publishing this article.

\section{Funding}

None

\section{Publishing Ethical and Originality Statement}

All authors declared that this work is original and has never been published in any form and in any media, nor is it under consideration for publication in any journal, and all sources cited in this work refer to the basic standards of scientific citation. 